\title{
SISI POSITIF TAQLIB DALAM SEJARAH PERKEMBANGAN HUKUM ISLAM
}

\author{
Ahmad Imam Mavard*
}

\begin{abstract}
A bstract: Themain prodem that this paper is interested in dealing with is thendion of taqlid, the Engish trandation of which bing a bind acceptance Taqlid is the qposite of Ijtihad theintelletual execise to draw etain legal nules from their sarces Mudims over centuries bedieved that taqlid in legal matters is not allowed, and that the dbor of Ijtihad has never been dosed, as some Westem schdars would emphatically argue Thepeper nonethdess maintains that taqlid daes take placein a major part of Islamiclegal histary. It has beecme unavidablefor Musims to accept blindly-dueto someresons thelegal viens of the grdier schdars andjurists But thepaper also argues that toaccept withait question theviens of the authoritativeschdarsinlegal mattersisnot alvays bad Thepapertriestoshouthat thereare -duetosomeconditions positivethingsin committingTaqlid Toshowthis, thepaper would attempt to smitinize thehistorical fads in whidh Musims do benfit fromding Taqlid It meansalsothat, IjtihadisnotalwaysgoodforMudims Bypresentingsomefindings-thepeper will argue that in somecases, Musims should abandonindependant intellectual exeriseand resat to bind acceptanceif in daingso would bring benfit for them
\end{abstract}

Keywords: Taqlid, Ijtihad, legal matters

\section{Pendahuluan}

Diskusi tentang ijtihaddan taqlidmenjadi neverendingthemedalam sejarah perkembangan hukum Islam, baik tentang definisi, eksistensi, urgensi maupun tentang implikasi sosialnya. Abad ke 20 Masehi menjadi saksi bergulirnya diskusi ini dengan dakhsyat di kalangan sarjana Barat, ketika isu insidad bab al-ijthad dijadikan obyek kajian. Adalah Joseph Schacht ${ }^{1}$ yang sering disebut sebagai sarjana Barat yang pertama kali berkeyakinan mapannya ketertutupan pintu ijtihaddalam sejarah perkembangan modern hukum Islam, ${ }^{2}$ yang meniscayakan lahirnya periode baru, yaitu periode taqii sejak akhir tahun $300 \mathrm{H} .{ }^{3}$ Perdebatanpun mengalir antara

\footnotetext{
*Fakultas Syariah dan Program Pascasarjana IAIN Sunan Ampel. Email: ai mawardi@yahoo.co.id, telp. $081330575770,081230272222,0818327547$.

${ }^{1}$ Lihat Joseph Schacht, "The Schools of Law and later D evelopment," dalam M. Khadduri dan H. Liebesny, Law in theMiddeEast (Washington D. C.: The Middle East Institute, 1955), 57-84; Lihat pula Joseph Schacht, An IntroductiontoIdamicLaw(O xford: Oxford University Press, 1964), 70.

${ }^{2}$ Sesungguhnya Joseph Schacht ini bukanlah orang yang pertama di kalangan sarjana Barat yang mengangkat wacana tertutupnya pintu ijtihad Sebelumnya sudah ada Snouck Hurgronje yang mengutip pendapat dari ulama Shafi' i>Ibrakim al-Bajutił w. 1276/ 1860) yang menyatakan bahwaijtihadsebagai upaya untuk menentukan putusan hukum langsung dari al-Q ur'an dan al-Sunnah sudah mulai surut sejak tahun $300 \mathrm{H}$. Th. W. Juynboll ketika membahas tema yang sama juga merujuk pada kutipan Snouck Hurgronje tersebut. Snouck Hurgronje yang ditulis dalam, "E Sachau: Muhammeanishes Recht nach schâfiitisher Lehre Berlin 1897," Zètshnift derDeatsher MorgenändschenGessdlscheft, liii (1899), 141-2. Lihat Lutz Wiederhold, "Legal D octrines in Conflict the Relevance of Madhhab Boundaries to Legal Reasoning in the Light of an Unpublished Treatise on Taqlîd and Ijtihad," dalam IdamicLawandSoiey, Vol. 3, N o. 2, Issues and Problems, (1996), 235.

${ }^{3}$ Tentang era kemapanan mazhab yang melambangkan menurunnya tradisi ijtihadterdapat perbedaan pendapat yang cukup tajam antara N.J. Coulson dan Joseph Schacht. Menurut Coulson ini terjadi pada sekitar akhir abad ketiga/ kesepuluh. Lihat N.J. Coulson, A Histaryof IdamicLaw(Edinburgh: Edinburgh University Press, 1964), 7, 9, 86-9; Sementara menurut Schacht hal ini tidak mencapai puncaknya sebelum tahun 700/ 1300. Lihat Joseph Schacht, AnIntroductiontoIdamicLaw65-67. Pendapat yang lain, yang menengahi perbedaan ekstrem kedua tokoh di atas juga muncul dari beberapa sarjana. Salah satunya adalah Shak Waliłllah al-D ahlawiłw. 1763) yang menyatakan
} 
yang memandang taqiidsebagai sesuatu yang negatif ${ }^{4}$ dan yang memandangnya secara positif sebagai keniscayaan perjalanan sejarah perkembangan hukum. ${ }^{5}$

Taqiid menurut makna etimologis yang disepakati oleh para ulama berasal dari kata calladayang bermakna "meletakkan tali/ ikatan di sekitar leher." ${ }^{\prime \prime}$ Istilah ini digunakan untuk menyiratkan kebergantungan seseorang pada orang lain. Sementara secara terminologis, para usjliyyun cenderung sepakat pada satu makna walaupun agak berbeda dalam redaksionalnya, yaitu makna yang diwakili oleh al-G hazali sebagai qabut qauk al-ghayr min ghayr hlyjjah (menerima pendapat orang lain tanpa adanya bukti/ hujjah) ${ }^{7}$ atau oleh al-Jurjani> sebagai 'ibarah an ittibas al-insar ghayrah fi>ma>yaqu aw yaf'al mitacican li al-haciqah fih min ghayr nez) wa táammil fi al-dalis (istilah untuk mengikutinya seseorang pada pendapat atau perilaku orang lain dengan meyakini kebenarannya tanpa berfikir dan merenungkan dalilnya),

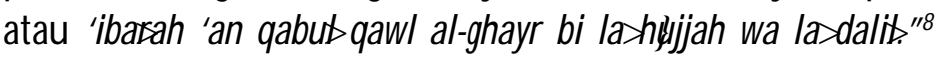

Praktek taqlid memang sudah menjadi kenyataan sejarah. Baik yang pro dan yang kontra sama-sama memiliki pondasi pijakan. D alam tataran dogmatis, kelompok pro tadied menggunakan al-Q ur'an antara lain Surat 21 (al-Abiyas): 7, ${ }^{9}$ Surat 4 (al-Nisas): $59^{10}$ dan surat 16 (al-Nahl): $43^{11}$ sebagai justifikasinya. Sementara kelompok yang kontra menggunakan ayat lainnya sebagai dalil larangan taqlid, antara lain surat 9 (al-Tawbah): $31,^{12}$ surat 43 (alZukhrut: $23^{13}$ dan surat 33 (al-Ahłaba): 67. ${ }^{14}$ Di samping pertarungan dengan menggunakan

bahwa era tersebut terjadi pada akhir abad kelima/ sebelas. Lihat Shak WaliæAllah al-D ahlawi>HrijjatAllahalBalighah(K airo: D apal-Turath, tt.), 1:152.

${ }^{4}$ Imagenegatif taqlidini bisa secara jelas dilihat dari bagaimana taqlidini dimaknai dan diterjemahkan. 0 rientalis cenderung menerjemahkan taqidini dengan istilah Inggris "blind following" atau "imation" sebagaimana dilakukan oleh Coulson dalam A Histaryof IdamicLaw, 80, atau "servile imitation," sebagaimana dicantumkan oleh G eorge Makdisi dalam TheRise of Colleges Institutions of LeaminginIslamand theWest(Edinburgh: Edinburgh University Press, 1981), 4, atau sebagai unquistioningaccettance of thedbtrines of establishedshods and authorities sebagaimana yang dikemukakan oleh Schacht, IntroductiontoIsamicLaw71.

${ }^{5} \mathrm{~K}$ ajian-kajian sosial terhadap ijtihaddan tadidini cenderung melihatnya sebagai sebuah kewajaran sosial bahkan secara positif melihatnya memiliki implikasi-implikasi sosial yang tidak selamanya merugikan. Lihat misalnya, Sherman Jackson, "Taqlid, Legal Scaffolding and the Scope of Legal Injunctions in Post-Formative Theory Mut\}laq and 'A mm in the Jurisprudence of Shihab al-Din al-Q arafil', dalam IdamicLawandSodidy, Vol. 3, No. 2, Issues and Problems, (1996), pp. 165-192; lihat juga Mohammad Fadel, "The Social Logic of Taqlid and the Rise of the Mukhtasqar," dalam IsamicLawandSocidy, Vol. 3, No. 2, 1996.

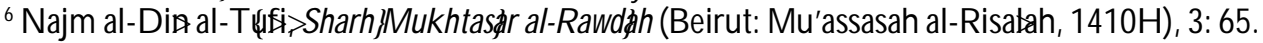

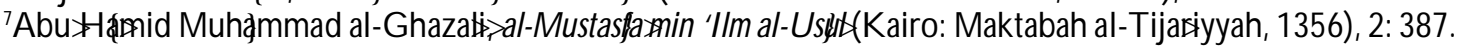

${ }^{8}$ al-Sharif 'Aliłoin Muhłmmmad al-Jurjani>Kitabal-Tánifate(Singapore, Jeddah: al-H łramayn, tt), 64.; Bandingkan dengan 'Abd Allah al-Fawzan, Sharh al-Waraqat(Riyadh: Dasal-Muslim, 1417), 260; Shaikh Bakr A buZayd, AlMadkhal al-Mufasjal ilaFiqhImanA hhadb Hanbal (Riyadh: D aral-Tawhijd, 1411), 1: 64.

9 "Kami tiada mengutus rasul-rasul sebelum kamu (Muhammad), melainkan beberapa orang laki-laki yang Kami beri wahyu kepada mereka, maka tanyakanlah olehmu kepada orang-orang yang berilmu, jika kamu tiada mengetahui." (al-Anbiya? 7)

10 "Hai orang-orang yang beriman, taatilah Allah dan taatilah Rasul (Nya), dan ulil amri di antara kamu. Kemudian jika kamu berlainan pendapat tentang sesuatu, maka kembalikanlah ia kepada Allah (al-Qur'an) dan Rasul (sunnahnya), jika kamu benar-benar beriman kepada Allah dan hari kemudian. Yang demikian itu lebih utama (bagimu) dan lebih baik akibatnya." (al-Nisa 5 59)

${ }^{11} \mathrm{D}$ an K ami tidak mengutus sebelum kamu kecuali orang-orang lelaki yang Kami beri wahyu pada mereka; maka bertanyalah kepada orang yang mempunyai pengetahuan jika kamu tidak mengetahui." (al-Nahl: 43)

12 "Mereka menjadikan orang-orang alimnya dan rahib-rahib mereka sebagai Tuhan selain Allah dan (juga mereka mempertuhankan) al-Masih putera Maryam; padahal mereka hanya disuruh menyembah Tuhan Yang MahaEsa; tidak ada tuhan (yang berhak disembah) selain Dia. Maha Suci Allah dari apa yang mereka persekutukan." (alTawbah: 31)

${ }^{13} \mathrm{D}$ an demikianlah, Kami tidak mengutus sebelum kamu seorang pemberi peringatanpun dalam suatu negeri, 
nas\$al-Q ur'an, sunnah Nabi pun menjadi landasan masing-masing kelompok. ${ }^{15}$

D alam tataran intelletual dscarse kelompok pro taqlidmenyatakan bahwa mengambil hukum langsung pada al-Q ur'an dan al-Sunnah sangatlah sulit dan kompleks karena, petama, membutuhkan syarat-syarat intelectual quality yang cukup berat dan, kedua, kesulitan untuk mendapatkan bahan-bahan yag komprehensif yang bertebaran dan tidak terkodifikasi dengan baik sebagai pertimbangan hukum. ${ }^{16}$ Alasan ini dibantah oleh al-Shawkaniyang menyatakan bahwa kompendiun (mkktasar) yang mencakup semua dalil yang dibutuhkan untuk ijtihad sebenarnya sudah ada dan cukup sebagai dasar, sehingga tidak ada alasan lagi untuk taqlid ${ }^{17}$

Perdebatan tentang taqlidini belum berakhir dan tidak akan berakhir. Sampai saat ini dua kubu terus eksis, bahkan kemudian muncul kelompok ketiga sebagai kelompok moderat yang menyatakan bahwa taqliditu ada dua macam, yang dibolehkan dan yang dilarang. AlShanqitijengan apik menjelaskan dua model taqlidini dengan mendasarkan pada kemampuan berfikir seseorang sebagai indikatornya. O rang awam tanpa kemampuan berfikir dan mengakses kepada nass/secara mandiri dibolehkan untuk taqiid sementara yang sebaliknya adalah dilarang. ${ }^{18}$

Sayangnya, diskusi tentang taqlid ini sangat banyak pada ranah tekstual, dogma dan teoritis. Tidaklah banyak kajian taqlid yang dilakukan dengan menggunakan pendekatan sosio-historis, pendekatan dengan menyelami lautan data historis dengan melihat faktor sosial sebagai pendorong dinamika sejarah itu sendiri. Salah satu dari yang sedikit ini adalah tentang taqlid dalam kaitannya dengan kemunculan tradisi mikhtasar dalam sejarah hukum Islam yang ditulis oleh Mohammad Fadel dengan menggunakan pendekatan sosiologis. ${ }^{19}$ Kajian ini ingin mengisi kekurangan kajian taqid secara sosiologis.

\section{Taqlid: Antara Definisi dan Realitas Sosiologis}

Image negatif yang direkatkan kepada taqlï sangatlah tidak bisa dipisahkan dari dua hal: petama, adalah definisi taqlid yang dikemukakan oleh para ulama yang meletakkannya pada posisi vis a vis ijtihad. Secara hitam putih ada jurang besar dikotomik antara wilayah ijtihad, pada satu sisi, yang dilambangkan sebagai potensi dinamis perkembangan hukum dan wilayah taqlid pada sisi yang lain, yang dianggap sebagai ketidakberdayaan intelektual fuqaha'; kedua, adalah realitas hukum Islam di tangan para awam (grass root soiky) yang cenderung terlepas dari pengetahuan akan logika (metodologi) hukum Islam. Taqliddi tangan mereka seakan mempertegas potret kaku hukum Islam. Tetapi, potret semacam in tidaklah

melainkan orang-orang yang hidup mewah di negeri itu berkata: "Sesungguhnya kami mendapati bapak-bapak kami menganut suatu agama dan sesungguhnya kami adalah pengikut jejak-jejak mereka." (al-Zukhruf: 23)

${ }^{14}$ D an mereka berkata: "Ya Tuhan kami, sesungguhnya kami telah mentaati pemimpin-pemimpin dan pembesarpembesar kami, lalu mereka menyesatkan kami dari jalan łang benar)." (al-Ahł̧ab: 67)

${ }^{15}$ Penjelasan yang relatif lengkap dan baik tentang perdebatan dua kelompok ini dengan elaborasi dali dan interpretasinya bisa dibaca di Rudolph Peters, "Idjtihad and Taqlid in $18^{\text {th }}$ and $19^{\text {th }}$ Century Islam," dalam DieWdt desIdams New Series, Vol. 20, Issue 3/ 4, (1980), 131-145.

${ }^{16}$ Rudolph Peters, "Idjtihad and Taqlid, 138.

${ }^{17}$ Rudolph Peters, "Idjtihad and Taqlid, 139.

${ }^{18} \mathrm{Al}$-Shanqity Adhasal-Bayanfiłdahal-Qur'anbi al-Qur'an(Beirut: Mu'assasah al-Risałah, 1413), 97-98. Bisa juga dilihat dalam M. Hashim K amali, ThePriniples of IsamicJunisprudence(Cambridge: Islamic Text Society, 1997), 374-377.

${ }^{19}$ Mohammad Fadel, "The Social Logic of Taqlid and the Rise of the Mukhtasąr," dalam IdamicLawandSodidy, Vol. 3, No. 2, 1996. 
berlaku pada aplikasi taqlid yang dilakukan oleh para fugaha'satau oleh para umara's Taqied oleh masyarakat awam adalah berjalan di bawah kesadaran (subconsaience), ${ }^{20}$ sementara taqied oleh para fucaha'>dan umara'sadalah berdasar kesadaran (avareness) on damand projet.

Tentang definisi taqlid oleh para ulama, 'Abdul Karim Zaidan, seorang alim usklik> kontemporer dari Iraq menyatakan bahwa dari keseluruhan definisi yang ada dapat disimpulkan menjadi satu definisi singkat, yaitu akhdh ra'y al-ghayr bi lama'nifat dalilih wa wa laxqumatih ${ }^{21}$ Menurutnya, hukum dari taqlid adalah tercela dan tidak boleh. Salah satu alasannya adalah karena akan melahirkan fanatisme dan permusuhan, di samping juga menyalahi doktrin keharusan memahami shariłah yang menjadi implikasi dari kewajiban taat kepada Allah dan Rasulullah.22

D efinisi-definisi yang ada menyiratkan ketidakberdayaan intelektual para muqallid dan pada akhirnya meruntuhkan perkembangan bangunan hukum Islam. Bagaimana para sarjana Barat menerjemahkan dan mendefisikan taqlidini sudah disebutkan pada bagian awal kajian ini, dan hampir keseluruhan dari mereka mengamini definisi-definisi yang ada tanpa memberikan ruang kemungkinan yang lain yang mungkin terjadi dalam prakek taqidini.

D efinisi yang ada tidak mampu membaca tradisi tadidyang dilakukan oleh para ulama yang memiliki kapabilitas metodologis yang bagus. Ulama-ulama mazhab yang cenderung mengikuti (taqliel) pada ulama-ualama sesudahnya adalah kurang tepat kalau diposisikan sama dengan masyarakat awam dalam memahami dan melaksanakan hukum. Yang dilakukan oleh mereka adalah pilihan sadar. Ketika diletakkan dalam wilayah pilihan sadar, maka sesungguhnya praktek taqiidmereka tidak terlepas dari motif-motif. Inilah yang akan dibahas nantinya dalam perspektif sosiologis.

Lebih lanjut, definisi taqlid yang ada juga tidak mampu membaca taqlid yang secara sadar dipilih oleh pemerintah ketika harus membuat undang-undang. Sudah jamak diketahui bahwa mazhab yang dianut mayoritas penduduk cenderung menjadi pilihan hukum pemerintah ketika harus membuat kodifikasi. Pakistan dan Turki dengan kecenderungan mazhab Hanafi, Saudi Arabia dengan mazhab Hanbali, Maroko dengan mazhab Maliki, dan Indonesia dengan mazhab Shafi'i iadalah salah satu contoh yang dengan jelas bisa dipahami. Apakah taqii mereka harus dibaca degatif dan disamakan dengan taqiehya para awam yang melakukannya sebagai tradisi yang berkelanjutan tanpa sadar?

D engan demikian maka harus disadari bahwa ada perbedaan yang perlu dicermati antara taqiil dalam definisi dengan taqlid dalam realitas sosial. Ketika taqlid dibaca sebagai sebuah pilihan sadar, maka ia tidak terlepas dari motif dan implikasi yang terekayasa. Motif dan implikasi sosial dari taqlidyang dilakukan secara sadar ini sangat mungkin bercitra positif

${ }^{20}$ al-Jabiri menjelaskan dengan baik bahwa dalam ilmu psikologi dan sosiologi, perbuatan manusia adalakalanya berupa perbuatan yang dikehendaki sebagai respon sadar atas suatu hal dan adakalanya juga merupakan perbuatan yang dilakukannya berulang-ulang tanpa adanya suatu kesadaran, yang dalam psikologi disebut dengan bawah sadar yang, menurut Freud, berisikan impian dan motif terpendam manusia sejak kecilnya. Lebih jauh Jung menyatakan, bukan hanya motif terpendam indivisual masa kecilnya, termasuk pula cdletiveunconsiausyang berkembang sejak dahulu. al-Jabiri, Muhammad A bid. al-'Aql al-Siyasial-'A rabi:Muhhaddidatuhna Tajalliyjatuh(alDaval-Baydąs? al-Markaz al-T haqafiłl-'A rabi>1991), 10-11. Lihat pula sebagai bandingan Michael Palmer, Freudand JungonRdigion(London: Routledge, 1997), 94-95. O leh karenaitu, akan sangat baik kalau kita mampu memisahkan antara taqlid yang telah menjadi adat umum (kebiasaan tanpa sadar) dengan taqlidyang menjadi pilihan sadar.

${ }_{21}^{2}$ Abd al-Karim Zaydan, al-Wajizzi Usłlal-Fiqh(Beirut, Lebanon: Maktabah Risałah, 2001), 410.

${ }^{22}$ Ibid., 410-11. 
dalam peta perkembangan hukum Islam.

\section{Taqlid: Antara Hegemoni dan 0 toritas}

Sebagai fakta sosial, taqlid sesungguhnya tidak pernah ke luar sendiri dari sebuah alur sejarah perkembangan hukum Islam. Ijthad dan taqlid bukanlah dua hal yang berdiri sendiri secara eksklusif tanpa ada kerterhubungan. Itulah kesimpulan dari Sherman Jackson yang mencoba mendamaikan perseteruan akademis antara Schacht dan Hallaq tentang tertutupnya pintu ijtiha ${ }^{23}$ Yang menarik adalah bahwa taqlid itu sesungguhnya secara sosiologis harus dibaca sebagai tahap perkembangan dari masa formatif hukum di mana ijtihadmerupakan intellectual instrument yang paling otoritatif. Taqiel juga adalah instrumett atau alat penetapan hukum mana yang harus diberlakukan.

Yang terjadi sesungguhnya adalah hegemoni dan otoritas. Ada masa di mana ijtihad menghemoni taqid yaitu pada masa formatif hukum Islam dan ada saat di mana taqlid menghegemoni ijtiha yakni pada masa post-formative Hegemoni tidaklah bermakna penguasaan secara totalitas satu pada yang lainnya, melainkan ada bagian-bagian yang terlepas dari tendensi yang berlaku secara umum. ${ }^{24} \mathrm{D}$ ata argumentatif yang bisa dikemukakan di sini adalah adanya pandangan yang membolehkan taqlidpada masa formatif hukum Islam abad kedua/ kedelapan dan ketiga/ kesepuluh seperti pandangan Ahmad bin Hæhbal, Ishąe bin Rahawayh, Sufyan al-Thawriðdan al-Shaybani $\gamma^{5}$ sebagaimana juga ada ulama yang terus mengadvokasi aplikasi ijtihad pada masa post fommative, seperti 'Izz al-D in bin Abd al-Salam, Ibn Taymiyah, al-Suyutilsdan al-Shawkani>

Pembacaan sosiologis terhadap fakta sejarah tersebut di atas memiliki implikasi yang sangat positif terhadap pencitraan perkembangan hukum. Taqii bukanlah dasar untuk menuduh kurang qualifiechya fuqaha'>era post-fomative, melainkan upaya menghargai dan melanjutkan apa yang telah digapai oleh ulama-ulama sebelumnya. Melanjutkan tradisi bukanlah sesuatu yang negatif sepanjang tidak memunculkan persoalan-persoalan yang mengarah pada social disarder.

Lebih lanjut, ketika persoalan ijtihaddan taqlidini didudukkan dalam takaran otoritas, maka sesungguhnya kedua-duanya berada dalam upaya memegang otoritas. Yang pertama adalah masa pembangunan otoritas hukum Islam dan yang kedua adalah upaya mempertahankan otoritas yang ada. Oleh karena itulah taqlid merupakan upaya terakhir mempertahankan otoritas ini dengan mencantolkan pendapat pada mazhab tertentu. Rudolf Peter memberikan contoh yang terbaik dalam proses penjagaan otoritas ini dengan menyebut proses peralihan dari ijtihad ke taqlid yang berupa tingkatan-tingkatan (tabaqat) mujtahid. Tingkat pertama adalah para pendiri mazhab yang disebut dengan mitahid mitlaq yang disusul oleh mitahid fi al-madhab mitahid fi al-fatwa>dan kemudian tingkat terakhir adalah mugallid $^{26}$

\footnotetext{
${ }^{23}$ Sherman Jackson, "Taqlîd, Legal Scaffolding and the Scope of Legal Injunctions in Post-Formative Theory Mumlaq and 'Amm in the Jurisprudence of Shihâb al-Dîn al-Q arâfl,", 172-3. Baca pula buku Sherman A. Jackson, IsamicLawandTheState TheConstitutional Junisprudence of Shihabal-Dinal-Qarafi (Leiden: E. J. Brill, 1996), 96. ${ }^{24}$ Sherman Jackson, "Taqlîd, Legal Scaffolding and the Scope of Legal Injunctions in Post-Formative Theory Mumlaq and 'Amm in the Jurisprudence of Shihâb al-D în al-Q arâfî,", 172-3.

${ }^{25}$ Lihat al-G hazali, al-Mustasfas: $2: 384$.

${ }^{26}$ Rudolph Peters, "Idjtihad and Taqlid, 136. Pembagian tingkatan-tingkatan mujtahid ini bervariasi antara ulama
} 
Ketika otoritas ini dihubungkan dengan teori sosial dhanismaticauthorityWeber, maka akan semakin jelas bahwa taqlidini sesungguhnya bertalian erat dengan karisma yang telah dimiliki dan dinikmati oleh fucaha'sebelumnya pada masa formatif. Memang Weber bukanlah orang pertama yang menggunakan terma karisma dalam studi agama, ${ }^{27}$ tetapi dialah yang memberikan landasan dasar untuk penggunaannya secara teknis. Weber berpandangan bahwa karisma dan aksi-aksi rasional merupakan dua kekuatan innovatif yang sangat besar sepanjang dinamika sejarah. ${ }^{28}$

Weber dalam teorinya tentang Power andAuthoritymenyatakan bahwa ada tiga macam otoritas dalam perjalanan sejarah kekuasaan, hukum dan politik: traditional authority, legglrational authoritydan danismaticauthority. ${ }^{29}$ Klasifikasi semacam ini berangkat dari beragamnya fakta lapangan bahwa sumber dari sebuah otoritas tidak selalu memiliki departingpaint yang sama; ada yang bersumber dari sebuah tradisi kebiasaan yang sulit ditinggalkan dan ditanggalkan oleh masyarakat, ada yang bersumber dari sebuah aturan yang disepakati bersama dan ada pula yang berangkat dari sebuah extraddinary danismaticaura seorang tokoh atau pemimpin.

Secara singkat definisi Weber atas tiga tipe tersebut di atas adalah sebagai berikut. Traditional Authority adalah sebuah tipe otoritas di mana kekuasaan (power) dilegitimasi oleh kebiasaan lama. Chietainship dan monarki, sebagai contoh, senantiasa mendasarkan kekuasaannya pada otoritas tradisional, dan sepanjang catatan sejarah, fakta semacam ini memang menjadi sumber sebuah otoritas yang sangat ampuh. Pada kekuasaan semacam ini, kompetensi tidak menjadi persoalan (not a bigdkel) sepanjang ia bisa mendapatkan justifikasi dari tradisi. Dalam stratifikasi sosial masyarakat Indonesia, teori ini mampu menjelaskan otoritas yang diturunkan antar generasi para priyai atau keluarga besar pesantren dengan gelar "Raden," "G us," "Lora" dan lain sebagainya. D alam konteks hukum, traditional authority ini dapat ditemukan pada hukum-hukum tidak tertulis dan hukum-hukum yang kebanyakan memiliki nilai sakral.

Legal rational authorityadalah sebuah tipe otoritas di mana kekuasaan (power) dilegitimasi oleh sebuah aturan dan prosedur yang jelas dan pasti yang mengatur tentang hak dan kewajiban dari seorang nule. Tipe otoritas semacam ini dalam konteks sosial betul-betul menciptakan "division of powers" dalam makna yang sesungguhnya. Seorang polisi lalu lintas yang pangkatnya masih kopral memiliki kuasa lebih tinggi (otoritatif) dibandingkan seorang jaksa, hakim ataupun guru besar yang pangkat administratifnya lebih tingggi. D alam ranah hukum, kekuasaan semacam ini dapat ditemukan dalam hukum-hukum tertulis yang biasa dikembangkan dalam negara-negara modern.

yang satu dengan yang lainnya. Ada yang membaginya dengan detail dan ada pula yang secara global, namun intinya adalah sama, yakni menggambaerkan perjalan sejarah dan keterkaitan tingkatan yang satu dengan yang

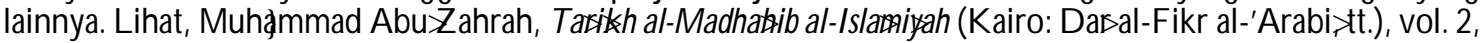
$112-122$.

${ }^{27}$ Weber sendiri mengakui bahwa karisma ini sebelumnya telah digunakan oleh Rudolf Sohm dalam kajian tentang agama. Lihat, S. N. Eisenstadt, ed., Max Weser onCharisma andInstitution Building(Chicago: University of Chicago Press, 1968), 19.

${ }^{28}$ Lihat Jonathan E. Brockopp, "Theorizing Charismatic Authority in Early Islamic Law," dalam Comparative IdamicStudies, no. 1, vol. 2 (2005); Peter Berger, "Charisma and Religious Innovation: The Social Location of Israilite Prophecy, " dalam Amrican Socidogical Reiew28 (1963), 940-950.

${ }^{29}$ Ian Robertson, Soadogy, edisi 3 (New York: Worth Publishers, Inc., 1988), 479-482. 
Sementara itu, darismaticauthoritydidefinisikan sebagai tipe kekuasaan yang dilegitimasi oleh kualitas yang unik dan luar biasa yang diatributkan kepada seorang pemimpin. Kualifikasi yang luar biasa ini oleh Weber disebut dengan istilah darism $\mathrm{A}^{30} \mathrm{D}$ alam konteks sosiologis, darisma ini tidak mesti dimiliki oleh orang-orang yang baik dalam pandangan umum. Sepanjang kehadirannya mampu mempengaruhi banyak orang dengan kemampuan "diri" nya yang luar biasa maka ia menjadi pemimpin yang berkharisma. D alam sejarah bisa disebut nama-nama seperti G andhi, Napoleon, Mao, Castro, Hitler, Sukarno, Suharto, Saddam Husein, dan lain sebagainya. Dalam kepemimpinan keagamaan bisa disebut Ayatullah Khomaini, Louis Farakhan, Paus Paulus, para wali dan sunan, dan lain sebagainya. Dalam konteks perkembangan hukum Islam, para pendiri mazhab adalah orang-orang yang memiliki kharisma luar biasa. Setiap pemimpin kharismatik senantiasa memiliki fatwa atau aturan yang sangat ditatati oleh para pendukungnya.

Oleh karena itu, akan sangat menarik kalau teori dharismaticauthorityini juga digunakan sebagai optik melihat latar belakang kemunculan tradisi taqiidsebagai sesuatu yang didukung oleh sebuah darisma. Tentu saja, darismatic authority yang dimaksud tidaklah murni seperti apa yang digagas oleh Weber, melainkan versi modifikasi. ${ }^{31}$ W. Montgomery Watt adalah salah satu contoh sukses penggunakan pendekatan ini dengan beberapa modifikasi ketika menggambarkan tentang darismatic commuity masyarakat muslim pada masa awal. ${ }^{32}$ Begitu pula Clifford G eertz yang dengan baik menggunakan teori Weber ini ketika menganalisa kharisma raja-raja di Maroko ${ }^{33}$ dan lain sebagainya. Di atas contoh ini, Edward Shils lah yang diakui oleh para sarjana so siologi sebagai orang pertama yang dengan baik memodifikasi teori darisma ini melampaui teori aslinya. ${ }^{34}$

In shat, peralihan ijtihadke taqieddengan pembacaan bahwa mqallidberupaya menjaga kesinambungan otoritas dan kharisma yang telah diperoleh oleh para mujtahid sebelumnya, dalam optik danismaticauthority harus dibaca sebagai proses penjagaan otoritas dengan tetap mempertahankan kharisma yang menjadi dasar enforsiabilitas sebuah aturan hukum. Karena itu tadidbukanlah potret ketidakberdayaan intelektual apalagi kemalasan akademis. Meskipun demikian, diakui atau tidak taqlidini memang memiliki potensi untuk memunculkan kondisi stagnan manakala tidak dibungkus oleh spint of lawitu sendiri.

Bukti kuatnya dugaan bahwa taqiid ini adalah proyek pelanjutan kharisma otoritas dan bukan hegemoni ulama lama atas abilitas intelektual ulama berikutnya adalah tiadanya indikasi persaingan ulama-ulama intra-mazhab antara yang senior (salaf) dengan yang yunior

${ }^{30}$ Chanismaini berasal dari bahasa Y unani yang berarti gitt of gace kelebihan wibawa, keagungan atau pesona.

${ }^{31}$ A da tiga keberatan untuk menggunakan teori dhansmaticauthorityWeber ini secara murni: pertama adalah bahwa katagori Weber ini memunculkan prodematic dichtamy antara pure harisma dan rautinized dhanisma; kedua, teori Weber ini telah ditentang dan secara signifikan mengalami beberapa perubahan; ketiga adalah bahwa untuk melihat perkembangan hukum Islam dengan kacamata ini memang diperlukan modifikasi karena menurut Weber karisma tidak merupakan bagian dari pengalaman kehidupan keberagamaan melainkan sebuah radica impulseyang meniscayakan penolakan terhadap struktur-struktur masyarakat.

${ }^{32} \mathrm{Di}$ samping karya W. Montgomery Watt yang berjudul IsamandtheIntegration of Sodidy, karya lainnya seperti Muhammed at Meeca dan Muhammed at Medina juga banyak menggunakan pendekatan darisma ini walaupun pengungkapannya tidak persis seperti yang dimaksud oleh Weber.

${ }^{33}$ Lihat Clifford G eertz, "Centers, Kings, and Charisma: Reflections on the Symbolics of Power," dalam Joseph Ben-D avid dan Terry Nichols Clark (eds), CultureandItsCreators EssaysinHonorof EdwardShils(Chicago: Chicago University Press, 1977), 150-171.

${ }^{34}$ Edward Shils, "Charisma, O rder, and Status, " AmericanSodogical Review30, no. 2 (1965), 199-213. 
(khalaff). Hal ini dapat dilihat misalnya dalam kitab Tałbaqab al-Fugaha'>dari setiap mazhab yang menggambarkan syndroric and sustained reation ketimbang conflid panorama di antara mereka.

\section{Taqlid dan Implikasinya dalam Pendekatan Social H istory}

Perkembangan sebuah ide bisa dibaca dengan utuh manakala faktor sejarah dan faktor sosial dijadikan sebagai data utama di samping landasan filofofis yang menjadi motor penggeraknya. Pendekatan social histary menawarkan piranti untuk tujuan ini.

Sepanjang pendekatan ini dilakukan, para sarjana memiliki berbagai pandangan terhadap latar belakang kemunculan tradisi tadidini. Coulson, misalnya, menyatakan bahwa taqiedmerupakan produksi dari sebuah model kemunduran sumber-sumber hukum Islam. ${ }^{35}$ Sementara itu, Joseph Schacht berpandangan bahwa taqlid merupakan imbas dari sempurnanya bangunan hukum yang dilakukan oleh para fuqaha'pada era formatif di samping juga kurang percaya dirinya (intelletual infeicity) para fucaha'>masa berikutnya. ${ }^{36}$ Tentang inferioritas taqlidterhadap ijtihadseperti ini, hampir seluruh sarjana sepakat dengan argumen and mode of artialation yang berbeda-beda. Kesimpulan Hallaq bahwa tradisi taqlid bukan hanya sebuah even negatif melainkan sebuah bentuk destruksi bangunan hukum Islam adalah cukup mewakili pandangan lainnya. ${ }^{37}$

Yang "tampil beda" adalah temuan Sherman Jackson yang dengan cerdas mengatakan bahwa secara sosial sebenarnya taqlid bukanlah karena intellectual ainfenionity sebagaimana dituduhkan oleh banyak sarjana, melainkan karena adanya keinginan para fuqaha'>untuk membatatasi kemungkinan pemerintah memanipulasi sistem hukum yang serba berubah atas nama ijtihad Adalah tidak fair untuk membahas ijjihad dan taqlid hanya dari sisi teoritis tanpa mencoba melihat peran apa yang dimainkan oleh keduanya dengan menggunakan pendekatan idealist discaurse ${ }^{38}$

Ikut meramaikan perdebatan kemunculan taqied ini, Weiss menyatakan bahwa taqied ini muncul juga karena tiadanya kejelasan (the problem of indteminag) prinsip-prinsip interpretasi yang netral dalam menyelesaikan masalah-masalah baru yang muncul. ${ }^{39} \mathrm{D}$ alam kondisi ini, taqiil adalah sebuah pilihan.

\footnotetext{
${ }^{35}$ Coulson, A Histary, 81.

${ }^{36}$ Schacht, AnIntroductiontoIsamicLaw70-1; Bandingkan pandangan Schacht ini dengan pendapat sarjana lainnya yang melihat dari faktor diluar hukum Islam. Al-Jabiri, misalnya, melihat adanya problematika struktural yang sangat akut pada sisi struktur nalar Arab dimana masa lampau selalu menjadi rujukan utama dalam pemikiran. Lihat, Issa J. Boullata, Dekonstruks Tradis, GdegarPenikiranArabIdam(Yogyakarta: LkiS, 2001), 65; lihat pula Lihat bahasan Muhammad 'A bid al-Jabiri, Takwinal-'Aql al-'Araby(Beirut: Markaz Dirasat al-Wihdah al-'Arabiyah, 1989), terutama pada bab 11; Lihat juga Muhłmmad Shahrur, sementara itu, memandang ketundukan pola pikir keislaman saat ini pada produk pemikiran abad III-V Hijriah seperti ini bermula dari naik daunnya mistisisme pada zaman al-G hazali dan Ibn Araby yang kemudian membungkam kreatifitas berfikir rasional. Masa ini, dalam dunia fiqh, dikenal dengan masa tertutupnya pintu ijtihad (insidad babal-ijtihad). Lihat Muhł̆mmad Shahrus, Dirasat Isariyjat:Mu'asiratefixl-Dankahnaal-Mujtama' (D amaskus: al-A haliłi al-Nashr, 1994), 217-223.

${ }^{37}$ Wael B. Hallaq, "Was the Gate of IjtihadClosed," dalam International Joumal of MiddeEastStudies16 (1984), 20; Lihat juga, "Considerations on the Function and Character of Sunni Legal Theory," dalam Jarnal of theAmerican Oriental Socidy, 104 (1984), 689.

${ }^{38}$ Sherman Jackson, "In D efence of Two-Tiered O rthodoxy," Disertasi Ph.D pada Univeritas Pennsylvania, 1991, $13,179$.

${ }^{39}$ Bernard Weiss, "Interpretation of Islamic Law," dalam AmericanJarmal of ComparativeLawNo. 26 (1978), 204.
} 
Bagaimanapun, taqlidmemang menyisakan banyak misteri. Maka, untuk melihat peran taqiid ini secara komprehensif, Mohammad Fadel mendata empat issue untuk dikaji. Dia menyatakan:

"When weattemt to undestand ijtihad and taqiil as an issuein thesocidogy of Isamiclaw as suggested by Weber, and with reference to the legal process of premoden Musim socieies as suggested by Jadkson, many interesting issues energe Among these is the comprenensiveness of taqlid Another is leegl dhange Presumally, if a régime of tadid was suffidently comprenensive, so that most situations were regulated by a nule, and if taqlid allowed for legitimate, reoogizable leegl dhange, many of Webe's digetions to it nould besatisfied A third issue, dosdy reated to the questions of leegl dhange, is therdationship of thelaw to fad, and whether or not interpreation of fact was consideredijibad or taqiid Another citical issueis thedstemination of what constituted a nulein a system govemed by ijtihad and what constituted a nulein a tadietbased system ${ }^{40}$

Analisa atas empat hal tersebut di atas akan membuka cakrawala pikir tentang taqij lebih cerah dan terbuka. Ternyata, ada peran-peran penting dan positif yang dimainkan oleh taqliddalam sejarah perkembangan hukum Islam. D alam hubungannya dengan aturan-aturan hukum yang secara empirik diterapkan, minimum ada tiga hal positif yang disumbangkan oleh taqii petama, adalah tegaknya kepastian hukum. D engan taqlid akan jelas pendapat yang mana dan mazhab yang mana yang dijadikan rujukan pelaksanaan hukum dan pengambilan keputusan hukum. Membiarkan ijthad menentukan masalah-masalah yang muncul akan menghilangkan leegl cetaintyyang sesungguhnya menjadi tema besar penegakan hukum dan keadilan kontemporer. Kedua, adalah munculnya tradisi kodifikasi yang merupakan kumpulan pendapat yang disepakati sebagai rujukan hukum. Tradisi kodifikasi ini juga merupakan trademark perkembangan hukum modern terutama dari mazhab Roman tradition Ketiga, adalah munculnya tradisi mikhtasagr ${ }^{11}$ dalam perkembangan klasik fiqih terutama sejak awal abad ketujuh/ ketigabelas juga merupakan dessingin dsguisedari tradisi taqlid ini.

\section{Penutup}

Taqiil ternyata memiliki imageganda: negatif dan positif. Imagenegatif tadid telah banyak diunggap oleh para sarjana, terutama mereka yang peduli dengan wacana teoritik. Bagi mereka taqiid tidak memiliki nilai positif apa-apa selain hanya potret ketidakberdayaan intelektual dan mandegnya perkembangan hukum Islam. Coulson, Schacht, dan Hallaq adalah di antara tokoh yang menganut aliran ini.

Bagi sarjana yang mau kreatif mendekati tradisi taqidini dari optik sosiologi hukum kontemporer, taqlił adalah fenomena biasa dan merupakan rangkaian dari sebuah perkembangan hukum Islam itu sendiri. Taqlid bisa dibaca sebagai penghargaan atas karya

${ }^{40}$ Mohammad Fadel, "Social Logic," 196; K husus tentang Weber pada poin yang kedua adalah berkenaan dengan pandangannya bahwa matinya ijtihad dalam perkembangan hukum Islam telah menutup hukum Islam itu sendiri untuk berposes secara modem menjadi hukum positif karena tidak mampu berdialog dengan spirit kapitalisme yang menjadi sebuah keniscayaan sejarah. Pada sisi inilah maka hukum adat dan sekuler yang sesungguhnya illigitimatemengisi ruang kosong yang ditinggalkan oleh kekakuan hukum yang diakibatkan oleh taqlid Lihat, Max Weber, EconamyandSodiey(Berkeley: University of California Press, 1978), 2:976.

${ }^{41}$ Bahasan tentang hubungan tadiddengan kemunculan tradisi mukhtasłar sangat baik ditulis oleh Mohammad Fadel, "The Social Logic of Taqlid and the Rise of the Mukhtasłar," dalam IsamicLawandSocidy, Vol. 3, No. 2, 1996. 
furaha'>sebelumnya yang dianggap sudah mapan, seperti kata Fadel, atau bahkan sebagai sebuah alat penentuan hukum ketika ada ketidakpastian metodologis yang bisa memberikan solusi atas permasalahan baru, seperti kata Bernard Weiss. Bahkan, dalam tataran empirik taqiel telah mendorong lahirnya kepastian hukum, tradisi kodifikasi dan tradisi mikhtasar dalam perkembangan fiqih.

Meskipun demikian, berhenti pada posisi taqlid dan membunuh ijtihad sebagai spint of Islamic law adalah pilihan yang sangat keliru ketika impian tatanan hukum Islam yang progresif masih perlu diwujudkan. Menarik untuk merenungkan ungkapan Khaled Abou El Fadl bahwa hukum Islam sesungguhnya masih hidup, tetapi piranti metodologis dan landasan epistemologinya telah mati. Inilah yang menjadikan hukum Islam stagnan dan tidak berdaya berdialog dengan realitas yang semakin berkembang. ${ }^{42}$

\section{Daftar Rujukan:}

Abu>Zahrah, Muhłgmmad. Takikh al-Madhakib al-Isapiyah Kairo: D as al-Fikr al-'Arabi>tt. A bu Zayd, Shaikh Bakr. Al-Madkhal al-Mufas sal ilaæFiqh ImamAhnadb Hanbal. Riyadh: D as al-Tawhile, 1411.

Anderson, J. N. D. LawReomin theMudimWodd London: The Athlone Press, 1974.

Berger, Peter. "Charisma and Religious Innovation:The Social Location of Israilite Prophecy, " dalam Ameican Socidogical Reiew28 (1963).

Boullata, Issa J. Dekanstruksi Tradisi, Gdegar Penikiran Arab Isam Yogyakarta: LkiS, 2001. Brockopp, Jonathan E. "Theorizing Charismatic Authority in Early Islamic Law," dalam Comparative Islamic Studies, no. 1, vol. 2 (2005).

Coulson, N. J. A Histary of IdamicLaw Edinburgh: Edinburgh University Press, 1964. al-D ahlawi> Shak Wali>Allah. Hxijat Allah al-Balighah K airo: D as al-Turath, tt.

Eisenstadt,S. N. ed. Max Weber on Chanisma and Institution Building Chicago: University of Chicago Press, 1968.

El Fadl, Khaled Abou. Speaking in God's Name Isamic Law Autharity and Women Oxford: Oneworld, 2001.

Fadel, Mohammad. "The Social Logic of Taqlid and the Rise of the Mukhtasłr," dalam Islamic Lawand Sociey, Vol. 3, No. 2, 1996.

al-Fawzan, 'Abd Allah. Sharh al-Waracat. Riyadh: D as al-Muslim, 1417.

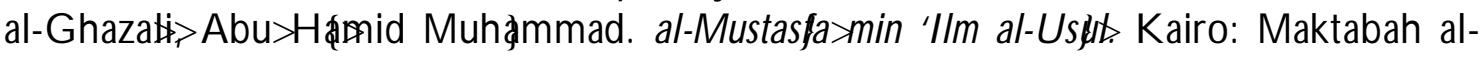
Tijaxiyyah, 1356.

Geertz, Clifford. "Centers, Kings, and Charisma: Reflections on the Symbolics of Power," dalam Joseph Ben-D avid dan Terry Nichols Clark (eds), Cultureand ItsCreators: Essays in Honor of Edward Shils Chicago: Chicago University Press, 1977.

Hallaq, Wael B. "Considerations on the Function and Character of Sunni Legal Theory," dalam Jaumal of the American Orietal Socidy, 104 (1984).

- - - - - "Was the G ate of Ijtihad Closed," dalam Intemational Jaumal of Midde East Studies 16 (1984).

\footnotetext{
${ }^{42}$ K haled A bou El Fadl, SpakkinginGod'sName IsamicLawAuthorityandWomen(O xford: O neworld, 2001), 171.
} 
Hurgronje, Snouck. TheAdhdnese, diterjemahkan oleh A.W.S. O'Sullivan. Leiden: E.J. Brill, 1906.

al-Jabiri, Muhammad 'Abid. Taknin al-'Aql al-Arabißeirut: Markaz Dirasat al-Wihdah al'Arabiyah, 1989.

- - - - . Al-Aqd al-Siyas >l-'Arabi>Muhaddidatuh wa Tajalliyjatuh Al-D as al-Baydla’ alMarkaz al-Thaqafy al-'Araby, 1991.

Jackson, Sherman A. "Taqlid, Legal Scaffolding and the Scope of Legal Injunctions in PostFormative Theory Mumlaq and 'A nmm in the Jurisprudence of Shihâb al-D în al-Q arâfî," dalam IsamicLawand Sodidy, Vol. 3, No. 2, Issues and Problems, (1996).

- - - - - . "In Defence of Two-Tiered Orthodoxy," Disertasi Ph.D pada Univeritas Pennsylvania, 1991.

- - - - - Islamic Law and The State The Constitutional Jurispudene of Shihab al-Din alQarafi. Leiden: E. J. Brill, 1996.

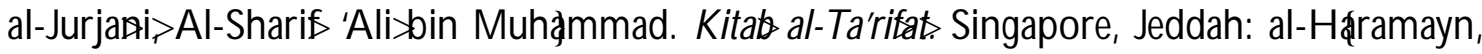
tt.

Kamali,M. Hashim. The Priniples of Isamic Junispudance Cambridge: Islamic Text Society, 1997.

Krawietz, Birgit. "Cut and Paste in Legal Rules: Designing Islamic Norms with Talfie,," dalam DieWdt des Isams, New Ser., Vol. 42, Issue 1 (2002).

Makdisi,G eorge. TheRise of Colleges Institutions of Lemingin Idamand theWest. Edinburgh: Edinburgh University Press, 1981.

Palmer, Michael. Frad and Jungon Reigion London: Routledge, 1997\}

Peters, Rudolph. "Idjtihad and Taqlid in $18^{\text {th }}$ and $19^{\text {th }}$ Century Islam," dalam DieWdt des Islams New Series, Vol. 20, Issue 3/ 4, (1980).

Robertson, Ian. Soidogy, edisi 3. New York: Worth Publishers, Inc., 1988.

Schacht, Joseph. "The Schools of Law and later D evelopment," dalam M. Khadduri dan H.

Liebesny, Lawin theMiddeEast (Washington D. C.: The Middle East Institute, 1955) Schacht, Joseph. An Introduction to Istamic Law Oxford: O xford University Press, 1964.

Al-Shanqitil> A dkkas al-Bayan fi>Idłh al-Qur'an bi al-Quran Beirut: Mu'assasah al-Risałah, 1413.

Shils, Edward. "Charisma, O rder, and Status, " American Socidogical Review30, no. 2 (1965). Shahrus, Muhłgmmad. Dirasat Isariyjat Múasirat fi ‘al-Dawat wa al-Mujtama'. D amaskus: alAhali li al-Nasyr, 1994.

al-T ulfi> Najm al-D in. SharhyMukhtasar al-Randkh Beirut: Mu'assasah al-Risałah, 1410H. Weber, Max. Econmy and Socidy. Berkeley: University of California Press, 1978.

Weiss, Bernard. "Interpretation of Islamic Law," dalam AmericanJaumal of ComparativeLaw No. 26 (1978).

Wiederhold,Lutz. "Legal D octrines in Conflict the Relevance of Madhhab Boundaries to Legal Reasoning in the Light of an Unpublished Treatise on Taqlad and Ijtihad," dalam IsamicLawand Sociey, Vol. 3, No. 2, Issues and Problems, (1996).

Zaydan, 'Abd al-Karim. Al-Wajiz fi Uskllal-Fiqh Beirut, Lebanon: Maktabah Risałah, 2001. 